http://dx.doi.org/10.5800/GT-2014-5-3-0148

\title{
TECTONICS AND EVOLUTION OF THE LITHOSPHERE OF THE EASTERN FRAGMENT OF THE MONGOL-OKHOTSK OROGENIC BELT
}

\author{
B. F. Shevchenko, L. I. Popeko, A. N. Didenko \\ Yu.A. Kosygin Institute of Tectonics and Geophysics, Far East Branch of RAS, Khabarovsk, Russia
}

\begin{abstract}
The article describes tectonics and the deep structure of the lithosphere in the eastern fragment of the MongolOkhotsk orogenic belt according to results of analysis of the geological and geophysical database. With account of palinspastic reconstructions, the model is developed to show the most probable paleogeodynamics of the lithosphere in the MongolOkhotsk orogenic belt and its heterochronous terrains.
\end{abstract}

Key words: comprehensive geological and geophysical studies, lithosphere model, tectonics, paleogeodynamical model of the Mongol-Okhotsk orogenic belt.

Recommended by D.P. Gladkochub

Citation: Shevchenko B.F., Popeko L.I., Didenko A.N. 2014. Tectonics and evolution of the lithosphere of the eastern fragment of the Mongol-Okhotsk orogenic belt. Geodynamics \& Tectonophysics 5 (3), 667-682. doi:10.5800/GT-2014-5-3-0148.

\section{ТЕКТОНИКА И ЭВОЛЮЦИЯ ЛИТОСФЕРЫ ВОСТОЧНОЙ ЧАСТИ МОНГОЛО-ОХОТСКОГО ОРОГЕННОГО ПОЯСА}

\author{
Б. Ф. Шевченко, Л. И. Попеко, А. Н. Диденко \\ Институт тектоники и геофизики им. Ю.А. Косыгина ДВО РАН, Хабаровск, Россия
}

Аннотация: На основе анализа комплекса геолого-геофизических данных проведено описание тектонического и глубинного строения литосферы восточной части Монголо-Охотского орогенного пояса. С учетом глобальных палинспастических реконструкций составлена наиболее вероятная палеогеодинамическая модель формирования литосферы Монголо-Охотского орогена и слагающих его разновозрастных террейнов.

Ключевые слова: комплексные геолого-геофизические исследования, модели литосферы, тектоника, палеогеодинамическая модель Монголо-Охотского орогенного пояса. 


\section{1. ВВЕДЕНИЕ}

Настоящая работа подготовлена для специального выпуска журнала «Геодинамика и тектонофизика», посвященного 60-летию Евгения Викторовича Склярова. Много лет он изучает геологию Центрально-Азиатского складчатого пояса. Такие работы Е.В. Склярова (лично и в соавторстве), как «Геология и метаморфизм Восточного Саяна» - 1998 г., «Эклогит-глаукофановые комплексы складчатых областей» - 1989 г., «Комплексы метаморфических ядер кордильерского типа» - 1989 г. и другие [Sklyarov, 2006; Sklyarov, Fedorovskiy, 2006; и дp.] существенно повлияли на мировоззрение исследователей ЦентральноАзиатского региона, в том числе и авторов статьи.

В представленной работе на основе новых геологогеофизических данных рассмотрено тектоническое и глубинное строение восточной части ЦентральноАзиатского складчатого пояса - Монголо-Охотского орогена, где в практику тектонических исследований последних лет вошло привлечение надежно обоснованных геохимических [Kovalenko et al., 1983; Kazimirovskiy, 2004; Tomurtogoo et al., 2005], геохронологических [Sorokin et al., 2004; Ruzhentsev, Nekrasov, 2009] и палеомагнитных данных [Didenko et al., 2010]. Такой подход в рамках концепции тектоники литосферных плит позволяет более надежно выстраивать палеогеодинамические (эволюционные) модели изучаемых территорий. Еще одной группой данных, которые дают возможность увеличить надежность различных построений, в том числе и прогнозных, являются 3D модели глубинного строения земной коры и верхней мантии. Подобные модели, полученные по результатам комплексной интерпретации геофизических материалов, позволяют дополнять и в определенной степени верифицировать тектонические и палеогеодинамические модели, которые в своем большинстве составляются на основании геологических данных, полученных на земной поверхности.

Рассматриваемая в работе территория исследований охватывает область, расположенную по южной границе Северо-Азиатского кратона, граничащего со структурами Центрально-Азиатского подвижного пояса (восточная часть Монголо-Охотского орогенного пояса). Здесь, помимо уже имеющейся новой геологической информации (геологические карты нового поколения, завершенные региональные тектонические построения по территории востока России и сопредельных стран), в последние годы в рамках проекта по созданию опорных глубинных профилей России (генеральный исполнитель СНИИГГиМС МПР РФ) выполнено значительное количество глубинных геофизических исследований земной коры (глубинное сейсмическое зондирование, профилирование методом МОВ-ОГТ, магнитотеллурическое зондирование). В сочетании с ранее полученными данными по гравиметрическим, магнитометрическим, геотермическим наблюдениям были составлены глубинные модели литосферного слоя изучаемой территории [Khanchuk, 2006; Didenko et al., 2013].

\section{2. ТЕКТОНИЧЕСКОЕ ПОЛОЖЕНИЕ МОНГОЛО-ОХОТСКОГО ПОЯСА}

Монголо-Охотский пояс в своей восточной части протягивается вдоль южной окраины Северо-Азиатского кратона. Западнее, на территории Забайкалья и Монголии, северным ограничением пояса является коллаж террейнов, аккретированных к Сибирскому кратону в конце позднего докембрия и раннем палеозое (рис. 1).

Южным ограничением пояса являются древние массивы (микроконтиненты или террейны): КеруленоАргунский, Мамынский и Буреинский, в составе которых устанавливаются докембрийские кристаллические образования, разнотипные рифейские метаморфические толщи, а также мощные деформированные терригенные и карбонатные отложения кембрия. Здесь же встречаются раннепалеозойские гранитные батолиты. Местами известны маломощные мелководные морские отложения девона, карбона, перми. Эти террейны южного обрамления Монголо-Охотского пояса являются, по существу, фрагментами раннепалеозойского орогенного пояса. Многие авторы [Zonenshain et al., 1990; Kozakov et al., 2005] обращают внимание на сходство в строении Керулено-Аргунского террейна и ТувиноМонгольского массива (микроконтинента), который располагается к западу и северо-западу от западного окончания Монголо-Охотского пояса.

\section{3. ТЕРРЕЙНЫ ВОСТОЧНОГО ЗВЕНА МоНГОЛО-ОХОТСКОГО ПОЯСА}

Опубликовано несколько схем выделения террейнов в пределах Монголо-Охотского орогенного пояса и его обрамления, которые заметно отличаются друг от друга [Natal'in, 1993; Gusev, Khain, 1995; Parfenov et al., 1996, 1999; Zorin et al., 1998; Nokleberg et al., 2000; Sorokin, 2001; Nokleberg, 2010; Khanchuk, 2006]. В предлагаемой схеме террейнового районирования (рис. 1) учтен опыт этих исследователей. В пределах Монголо-Охотского пояса выделяются вытянутые на сотни километров вдоль его простирания лентовидные структуры, которые по составу слагающих их пород и строению классифицируются как террейны аккреционного клина [Nokleberg et al., 2000]. Среди них различаются террейны двух типов [Parfenov et al., 1998]: террейны аккреционного клина, сложенные преимущественно турбидитами, и террейны аккреционного клина, сложенные преимущественно океаническими образованиями. К первому типу относятся Хангай-Даурский (западное звено пояса), Унья-Бомский, 


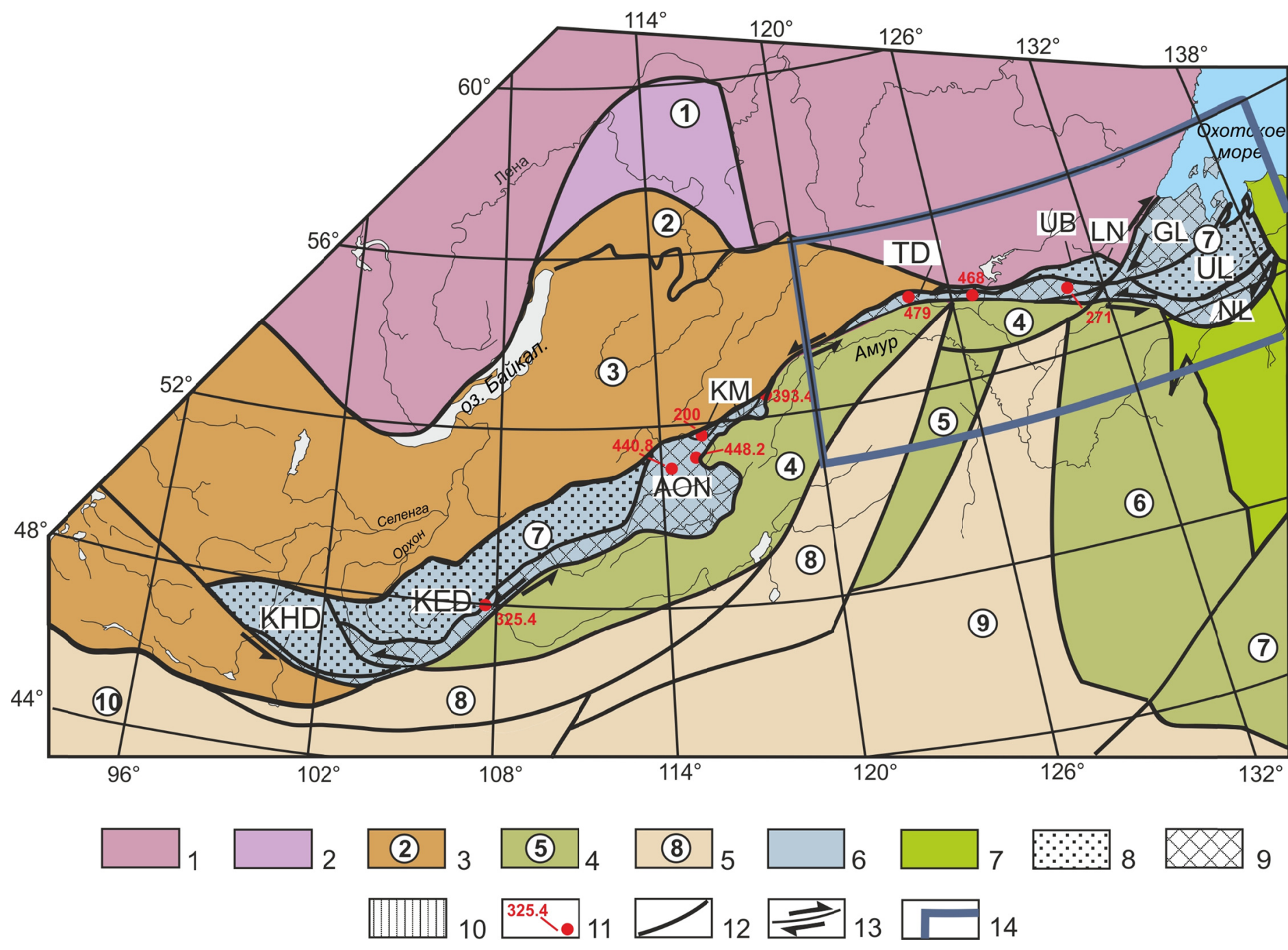

Рис. 1. Тектоническое положение Монголо-Охотского орогенного пояса и слагающих его террейнов.

Кратоны: 1 - Сибирская платформа; 2 - опущенная окраина кратона - Байкало-Патомский складчато-надвиговый пояс; 3 - террейны (орогенные пояса различного возраста), аккретированные к кратону в среднем рифее и кембрии (2 - Циркум-Сибирский, 3 - ЕнисейЗабайкальский); 4 - коллаж террейнов (орогенные пояса и их фрагменты, микроконтиненты) различного возраста: микроконтиненты (позднегерцинский Аргуно-Мамынский - 4, раннепалеозойский Дягдачи - 5, Цзямусы-Буреинский - 6, Ханкайский - 7); 5 - позднепалеозойские орогенные пояса (Северо-Хинганский - 8, Луньцзян-Селемджинский - 9, Атасбогдинский - 10); 6 - позднепалеозойскийраннемезозойский Монголо-Охотский орогенный пояс; 7 - Сихотэ-Алиньский позднеюрский-раннемеловой орогенный пояс; террейны Монголо-Охотского орогенного пояса: 8 - террейны А типа - аккреционная призма, состоящая в основном из турбидитов с меньшим количеством океанических ассоциаций (Хангай-Даурский террейн: KHD - Хангайский фрагмент, KED - Хэнтей-Даурский фрагмент; UB - Унья-Бомский, LN - Ланский, UL - Ульбанский); 9 - террейны B типа - аккреционная призма, состоящая в основном из океанических ассоциаций с меньшим количеством турбидитов (фрагменты Агинского террейна: AON - Ононский, TD - Тукурингра-Джагдинский, NL - Ниланский; GL - Галамский террейн); 10 - террейны островных дуг (KM - Каменский); 11 - месторасположение фрагментов океанической коры и их возраст в млн лет; 12 - разломы; 13 - разломы со сдвигом; 14 - контур площади исследований.

Fig. 1. Tectonic position of the Mongol-Okhotsk orogenic belt and its terrains.

Cratons: 1 - Siberian platform; 2 - subducted margin of the craton, Baikal-Patom thrust-folded belt; 3 - terrains (heterochronous orogenic belts) which are accreted to the craton in the Middle Riphean and Cambrian (2 - Circum-Siberian, 3 - Yenisei-Transbaikalian); 4 - collage of heterochronous terrains (orogenic belts and their fragments, microcontinents: Late Hercynian Arguno-Mamynsky - 4, Early Paleozoic Dyagdachi - 5, Tjamusy-Bureinsky - 6, Khankaisky - 7); 5 - Late Paleozoic orogenic belts (North-Khingansky - 8, Lunjan-Selemginsky - 9, Atasbogdinsky 10); 6 - Late Paleozoic - Early Mesozoic Mongol-Okhotsk orogenic belt; 7 - Late Jurassic-Early Cretaceous Sikhote-Alinsky orogenic belt; terrains of the Mongol-Okhotsk orogenic belt: 8 - terrains of type A - accretion prism composed mainly by turbidites with smaller amounts of oceanic assemblages (Khangai-Dauria terrain: KHD - Khangaisky fragment, KED - Khentei-Dauria fragment; UB - Unja-Bomsky, LN - Lansky, UL Ulbansky); 9 - terrains of type B - accretion prism composed mainly by oceanic assemblages with smaller amounts of turbidites (fragments of Aginsky terrain: AON - Ononsky, TD - Tukuringra-Dzhagdinsky, NL - Nilansky; GL - Galamsky terrain); 10 - oceanic arc terrains (KM - Kamensky); 11 - locations of oceanic crust fragments and their age (Ma); 12 - faults; 13 - faults with displacements; 14 - contour of the area under study. 
Ланский и Ульбанский террейны, ко второму типу Агинский и Галамский террейны. Большинство террейнов разобщено на фрагменты (субтеррейны), которые отстоят друг от друга на сотни километров или, наоборот, неоднократно совмещены друг с другом в плане в результате крупных (сотни километров) горизонтальных перемещений вдоль Монголо-Охотского пояса [Parfenov et al., 1999].

Унья-Бомский террейн располагается на северной окраине восточной части Монголо-Охотского пояса к северо-востоку от Тукурингра-Джагдинского субтеррейна (рис. 1, 2). Он представляет собой пакет пластин, сложенных позднетриасовыми и раннеюрскими турбидитами. С севера террейн ограничен надвигом, по которому слагающие его толщи надвинуты на Ланский террейн. С юга по разлому он контактирует с Тукурингра-Джагдинским субтеррейном [Kirillova, Turbin, 1979; Natal'in et al., 1985; Natal'in, 1993]. Наряду с преобладающими флишевыми отложениями присутствуют базальты, метаморфизованные в фации зеленых сланцев, глубоководные кремнистые и глинисто-кремнистые породы, а также мелководные образования, представленные конгломератами и песчаниками с растительным детритом, которые, вероятно, тектонически совмещены в едином разрезе. Отмечены олистостромовые горизонты, иногда достигающие значительной мощности (до 500 м). Среди олистолитов присутствуют мраморизованные известняки с вендскими(?) онколитами и катаграфиями, характерными для пород Северо-Азиатского кратона, а также известняки с позднепермскими мшанками [Kirillova, Turbin, 1979].

Вывод об определяющем значении крупных (в сотни километров) продольных перемещений вдоль Монголо-Охотского пояса подкрепляется изучением деформационной структуры пород Унья-Бомского террейна, которая определяется широким развитием линейности удлинения в виде минералов, минеральных агрегатов и галек конгломератов, вытянутых вдоль простирания пояса [Natal'in et al., 1985; Natal'in, Borukaev, 1991; Natal'in, 1991].

В зоне сочленения с Северо-Азиатским кратоном мезозойские терригенные толщи Унья-Бомского террейна несогласно перекрыты верхнеюрскими песчаниками, конгломератами, алевролитами, аргиллитами и нижнемеловыми конгломератами, песчаниками, алевролитами [Decisions..., 1995; Kozlovskiy, 1988]. Верхнеюрские отложения несогласно налегают также на докембрий кратона. Они смяты в простые пологие складки.

Ланский террейн расположен в восточной части Монголо-Охотского пояса на ее северной окраине (рис. 1, 2). Северная граница террейна с кратоном частично перекрыта отложениями Зейско-Удского осадочного бассейна. На юго-востоке по Улигданскому сдвигу он контактирует с Галамским террейном. В составе террейна присутствуют нижне?-среднедевонские, каменноугольные, верхнепермские, триасовые отложения, перекрытые юрскими образованиями Удского бассейна. Стратиграфический разрез Ланского террейна сложен турбидитовыми толщами с пластами яшм, базальтов, их туфов, диабазов, известняков. Терригенные отложения охарактеризованы остатками кораллов, брахиопод, криноидей, мшанок, аналогичных по составу распространенным в Тукурингра-Джагдинском фрагменте Агинского террейна, в одновозрастных отложениях Аргунского и Буреинского террейнов и многих районах Центральной Азии (Монголо-Охотская провинция) [Gratsianova, Shishkina, 1982; Popeko et al., 1993]. Присутствуют олистостромы, содержащие глыбы песчаников, алевролитов, известняков с силурийскими кораллами и раннекембрийскими археоциатами, погруженные в алевропелитовый матрикс. В северо-восточной части террейна палеозойские и триасовые отложения с резким угловым несогласием перекрыты мелководно-морскими толщами нижней и средней юры.

Дислокационная структура Ланского террейна изучена слабо. Известно, что слагающие его палеозойские осадочно-вулканогенные образования смяты в напряженные, крутые, иногда асимметричные складки линейного типа преимущественно северо-западного простирания [Kirillova, Turbin, 1979]. Складчатая структура нарушена системой субпараллельных разломов. Кинематика их не установлена. Характерно то, что, несмотря на весьма напряженную складчатость, в породах Ланского террейна, в отличие от расположеного к юго-западу от него Унья-Бомского, сланцеватость отсутствует.

Ульбанский террейн выделяется в восточной части Монголо-Охотского пояса (рис. 1, 2). Он сложен преимущественно верхнетриасовыми и нижне-среднеюрскими турбидитами, тектонически смешанными с небольшими объемами среднеюрских кремней и метабазальтов и, в целом, характеризуется последовательной сменой с юга на север более древних отложений более молодыми. Проведенный Б.А. Натальиным [Natal'in, 1993] кинематический анализ свидетельствует о южном направлении перемещений.

Агинский террейн, прослеживающийся на протяжении большей части Монголо-Охотского пояса, состоит из трех фрагментов (субтеррейнов): Ононского (западное звено) и Тукурингра-Джагдинского (восточная часть), расположенных на простирании друг друга, но разобщенных на 200 км в верховьях р. Амур в месте пережима всего орогенного пояса, а также продолжающего их на востоке Ниланского фрагмента (рис. 1, 2).

Примечателен коленообразный в плане изгиб Ононского фрагмента в районе Восточного Забайкалья, известный как Восточно-Забайкальская сигмоида. Форма сигмоиды свидетельствует о левостороннем сдвиговом смещении вдоль Монголо-Охотского пояса примерно на 100 км. Террейн образован серией покровных пластин, различающихся по вещественному составу и 


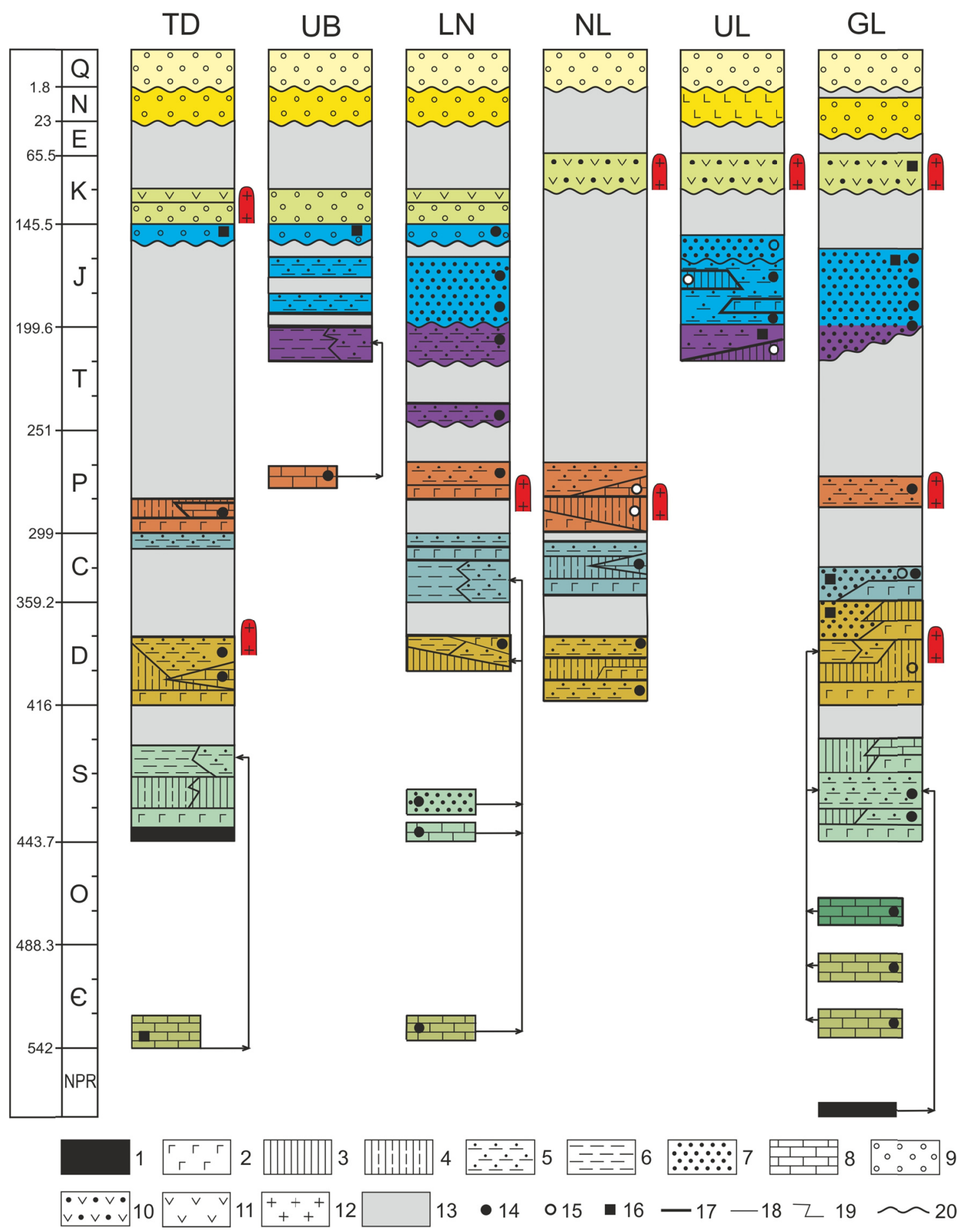

Рис. 2. Сводные тектоно-стратиграфические колонки террейнов восточной части Монголо-Охотского орогенного пояса.

1 - габброиды; 2 - океанические базальты; 3 - глубоководные кремнистые отложения; 4 - глубоководные кремнисто-глинистые отложения; 5 - турбидиты; 6 - алевропелитовые отложения; 7 - мелководные морские отложения; 8 - известняки; 9 - континентальные кластические отложения; 10 - надсубдукционные вулканические пояса; 11 - бимодальные вулканиты; 12 - гранитоиды; 13 - стратиграфический перерыв; 14 - морская макрофауна; 15 - морская микрофауна; 16 - растительные остатки; 17 - тектонический контакт; 18 - стратиграфический контакт; 19 - фациальный контакт; 20 - угловое несогласие. Террейны: TD - Тукурингра-Джагдинский, UB - УньяБомский, LN - Ланский, NL - Ниланский, UL - Ульбанский, GL - Галамский.

Fig. 2. Consolidated tectonic stratigraphic columns of terrains of the eastern regions of the Mongoll-Okhotsk orogenic belt.

1 - gabbroids; 2 - oceanic basalts; 3 - deep-water silicious sediments; 4 - deep-water silicious-clayey sediments; 5 - turbidites; 6 - aleuropelitic sediments; 7 - shallow-water marine sediments; 8 - liemstones; 9 - continental clastic sediments; 10 - suprasubduction volcanic belts; 11 - bimodal volcanic rocks; 12 - granitoides; 13 - stratigraphic gap; 14 - marine macrofauna; 15 - marine microfauna; 16 - vegetal debris; 17 - tectonic contact; 18 - stratigraphic contact; 19 - facial contact; 20 - angular unconformity. Terrains: TD - Tukuringra-Dzhagdinsky, UB - UnjaBomsky, LN - Lansky, NL - Nilansky, UL - Ulbansky, GL - Galamsky. 
возрасту слагающих их отложений [Ruzhentsev, Nekrasov, 2009]. В рассматриваемых субтеррейнах присутствуют фрагменты разновозрастных офиолитов.

Значительный объем Тукурингра-Джагдинского субтеррейна слагают вулканиты, кремнистые, кремнисто-глинистые с линзами известняков и терригенные породы, метаморфизованные в фации зеленых сланцев. Метаморфические зеленосланцевые толщи известны под названием янканской серии, первоначально относимой к рифею - венду [Geology of the USSR, $1966]$ на основании присутствия в известняках онколитов и катаграфий, стратиграфическая значимость которых дискуссионна. Позднее серия датировалась силуром-девоном [Kirillova, Turbin, 1979], а также ранним, средним или средним-поздним палеозоем [Krasnyi et al., 1999]. В настоящее время для метавулканитов из низов серии получена U-Pb датировка $479 \pm 7.6$ млн лет. Приведенные данные позволяют предполагать существование океанического бассейна на месте Монголо-Охотского орогенного пояса в ордовике - силуре.

Ниланский фрагмент включает традиционно выделявшийся Ниланский антиклинорий, сложенный среднепалеозойскими (?), девонскими, каменноугольными и пермскими толщами, среди которых, наряду с преобладающими глинистыми, кремнисто-глинистыми образованиями и зеленокаменно-измененными базальтами, присутствуют горизонты турбидитов. В западной части фрагмента средне-позднепалеозойские толщи подвержены интенсивному рассланцеванию и метаморфизму с образованием куполов.

Ряд признаков позволяет предполагать аккреционную природу Агинского террейна и его субтеррейнов, в частности чешуйчато-надвиговая структура, характерное для аккреционных призм совмещение мелководных терригенных отложений с породами океанического дна, присутствие метаофиолитов [Natal'in et al., 1985] и глаукофановых сланцев [Dobretsov et al., 1998], совмещение базальтов типа MORB и OIB [Sorokin, 2001], образовавшихся в разных геодинамических обстановках, присутствие в известняках, ассоциированных с вулканитами, раннепермских тетических фузулинид и кораллов [Kirillova, Turbin, 1979], являющих резкий контраст с позднепалеозойской бореальной фауной, характерной для других террейнов МонголоОхотского пояса и его обрамления. Однако в Тукурингра-Джагдинском фрагменте, зажатом между жесткими континентальными блоками, эти признаки затушеваны коллизионными деформациями.

Проведенный здесь структурный анализ дислокаций показал, что они образовались в шесть этапов [Natal'in et al., 1985; Natal'in, 1991]. Основная структурообразующая роль принадлежит деформациям второго этапа, результатом которых явилась система субширотных лежачих и опрокинутых изоклинальных складок и надвигов с северной вергентностью. Складчатость сопровождалась зеленосланцевым метамор- физмом и формированием сланцеватости, параллельной осевым поверхностям складок и слоистости. Стиль коллизионных деформаций в Тукурингра-Джагдинском и Унья-Бомском террейнах одинаков. В УньяБомском террейне и северной части Тукурингра-Джагдинского фрагмента Агинского террейна слоистость и сланцеватость залегают субгоризонтально, что свидетельствует о покровном строении района. Корни покровов находятся в южной части Тукурингра-Джагдинского фрагмента, характеризующейся крутыми падениями сланцеватости [Natal'in et al., 1985]. По ширине района с субгоризонтальным залеганием сланцеватости амплитуда надвигания структур МонголоОхотского пояса на Северо-Азиатский кратон оценивается в 50 км. Наряду с перемещением масс к северу и северо-востоку (в современных координатах), происходило пластическое течение вещества по простиранию террейнов при их сдвиговой транспортировке. Свидетельством этого является повсеместное развитие линейности растяжения, параллельной шарнирам опрокинутых складок и ориентированной по простиранию террейнов.

Сдвиг в условиях сжатия, обусловленного совместным движением на северо-восток микроконтинентов и террейнов, расположенных к югу от Монголо-Охотского орогенного пояса, привел к выдавливанию структур Тукурингра-Джагдинского и Унья-Бомского террейнов на Северо-Азиатский кратон. Перед фронтом выжимающихся к северу монголо-охотских структур сформировался Удско-Зейский передовой прогиб [Natal'in, 1991]. Выполняющие его верхнеюрско-нижнемеловые образования не обладают сланцеватостью и не несут следов метаморфических преобразований. Это дает основание оценить возраст формирования основных деформационных структур в ТукуринграДжагдинском террейне как конец средней - начало поздней юры.

Галамский террейн, расположенный на северовосточном окончании Монголо-Охотского пояса (рис. 1, 2), обладает чешуйчато-надвиговой структурой. Каждая из тектонических пластин и чешуй сложена породами одной из трех ассоциаций пород раннесреднепалеозойского возраста, которые тектонически совмещены и неоднократно повторяются в разрезе: 1) яшмы, ленточные кремни, кремнисто-глинистые сланцы, базальты; 2) терригенные слоистые толщи с признаками турбидитовой седиментации; 3) олистостромы, содержащие включения нижнекембрийских известняков, кремнистых известняков, кремнистых пород и диабазов [Natal'in, Popeko, 1991; Natal'in, 1993]. Таким образом, в пределах террейна присутствуют ассоциации совершенно разных и значительно удаленных друг от друга обстановок седиментации - континентального склона и его подножья, с одной стороны, и абиссальной равнины - с другой. В современной структуре каждая ассоциация пород отделена от смежной зоной вязких разломов, подчеркнутых интенсив- 
ным разлинзованием и будинажем, сланцеватостью со структурами течения, транспозиционными структурами. Ориентировка плоскостей разломов субпараллельна слоистости во внутренних, обычно слабонарушенных, частях чешуй и пластин. Перечисленные особенности позволяют рассматривать палеозойский комплекс Галамского террейна как субдукционный. Пермские отложения, представленные конгломератами и песчаниками с флорой, слагают небольшие, ограниченные разломами клинья [Roganov, 1976]. Триасовые и юрские терригенные отложения Торомского преддугового прогиба характеризуются сравнительно простыми дислокациями. Они перекрывают аккреционный комплекс с угловым несогласием [Natal'in, 1993].

Традиционно Галамский террейн [Kozlovskiy, 1988; Natal'in, 1991; Krasnyi et al., 1999] относится к Монголо-Охотскому поясу. Однако строение его существенно отличается от такового других террейнов пояса. В частности, в нем присутствуют палеоокеанические образования кембрия, в то время как в остальных террейнах палеоокеанические комплексы имеют возраст не древнее ордовика-девона. Анализ таксономического состава раннекембрийских археоциат свидетельствует о своеобразии галамских комплексов. Комплексы археоциат второй половины раннего кембрия резко отличаются от одновозрастных комплексов Дальнего Востока России и принадлежат к Кордильеро-Корякской биогеографической провинции [Belyaeva, 1987; Khanchuk, Belyaeva, 1993]. Силурийские и ранне-среднедевонские фауны этого террейна обнаруживают сходство с фаунами северо-востока России в отличие от одновозрастных сообществ других террейнов Монголо-Охотского пояса и его южного обрамления, демонстрирующих родство с фаунами Центральной Азии [Parfenov et al., 1999].

Вероятно, Галамский аккреционный клин относится к восточной (в современных координатах) активной окраине Азии и занял свое современное положение в результате правосторонних сдвиговых перемещений вдоль Монголо-Охотского пояса в самом конце мезозоя. Правые сдвиги отмечены как на северной границе (Улигданский сдвиг) [Kirillova, Turbin, 1979], так и внутри Галамского террейна [Natal'in, Borukaev, 1991]. Правосторонние сдвиговые смещения можно предполагать по зоне Южно-Якутских разломов, в южном крыле которых юрские интрузивные массивы, представляющие собой трещинные тела, образуют левосторонний эшелон [Parfenov et al., 1979]. Ранее Галамский террейн располагался значительно северо-восточнее. Сопряженная с ним магматическая дуга может быть представлена фрагментами средне-позднедевонского вулканоплутонического пояса, которые известны на Охотском массиве. Аянский террейн, расположенный к северо-востоку от Галамского террейна на побережье Охотского моря и образованный силурийскими и девонскими обломочными и карбонатными породами, в том числе флишем (до 2000 м), может представлять фрагмент преддугового прогиба данной активной континентальной окраины [Parfenov et al., 1999].

По набору пород Галамский террейн имеет сходство с Ганычаланским террейном в Корякском нагорье [Khanchuk et al., 1992]. Все это позволяет рассматривать Галамский террейн как фрагмент Охотско-Корякского орогенного пояса [Khanchuk, 2000].

\section{4. СОВРЕМЕННОЕ СТРОЕНИЕ ЛИТОСФЕРЫ ОБЛАСТИ ИССЛЕДОВАНИЙ}

Монголо-Охотский орогенный пояс практически полностью (за исключением Хангайского фрагмента Хангай-Даурского террейна) расположен в пределах современной Амурской литосферной плиты (рис. 1-3).

Для орогена в целом характерно сокращение мощности литосферного слоя. Для западного фрагмента значения мощности составляют 100-80 км, а для восточного - 80-60 км. Незначительные величины мощности литосферного слоя относительно кратонных областей (160 км и более) свидетельствуют о наличии в этой части Амурской плиты останцев литосферы океанического типа.

Близкое расположение в плане внутриплитовых глубинных границ для западного фрагмента орогена (зоны максимального градиента мощности литосферного слоя) с разломными системами северо-восточного простирания на земной поверхности со сдвиговой составляющей [Tectonics..., 2008] предполагает крутое падение плоскостей глубинных разломов. Для восточного фрагмента характерно расхождение глубинных и приповерхностных границ раздела (рис. 3) что свидетельствует о пологом падении.

Различие указанных структурных планов между западным и восточным фрагментами Монголо-Охотского орогена обусловлено как различным временем окончательного формирования его частей (не одновременное закрытие Монголо-Охотского палеобассейна), так и различием тектонических стилей формирования коллажа литосферных террейнов, составляющих Амурскую плиту. В частности, для западного фрагмента Монголо-Охотского орогена преобладающий стиль - косая коллизия, а для восточного - субдукция.

Детерминированное во времени формирование земной коры области сочленения в целом и МонголоОхотского орогена в частности прослеживается в различной морфологии поверхности земной коры (граница Мохоровичича). Если для западного фрагмента орогена контрастных структурных элементов не установлено, то восточный фрагмент расположен в зоне интенсивного субширотного градиента мощности коры, который и предопределил ориентировку 


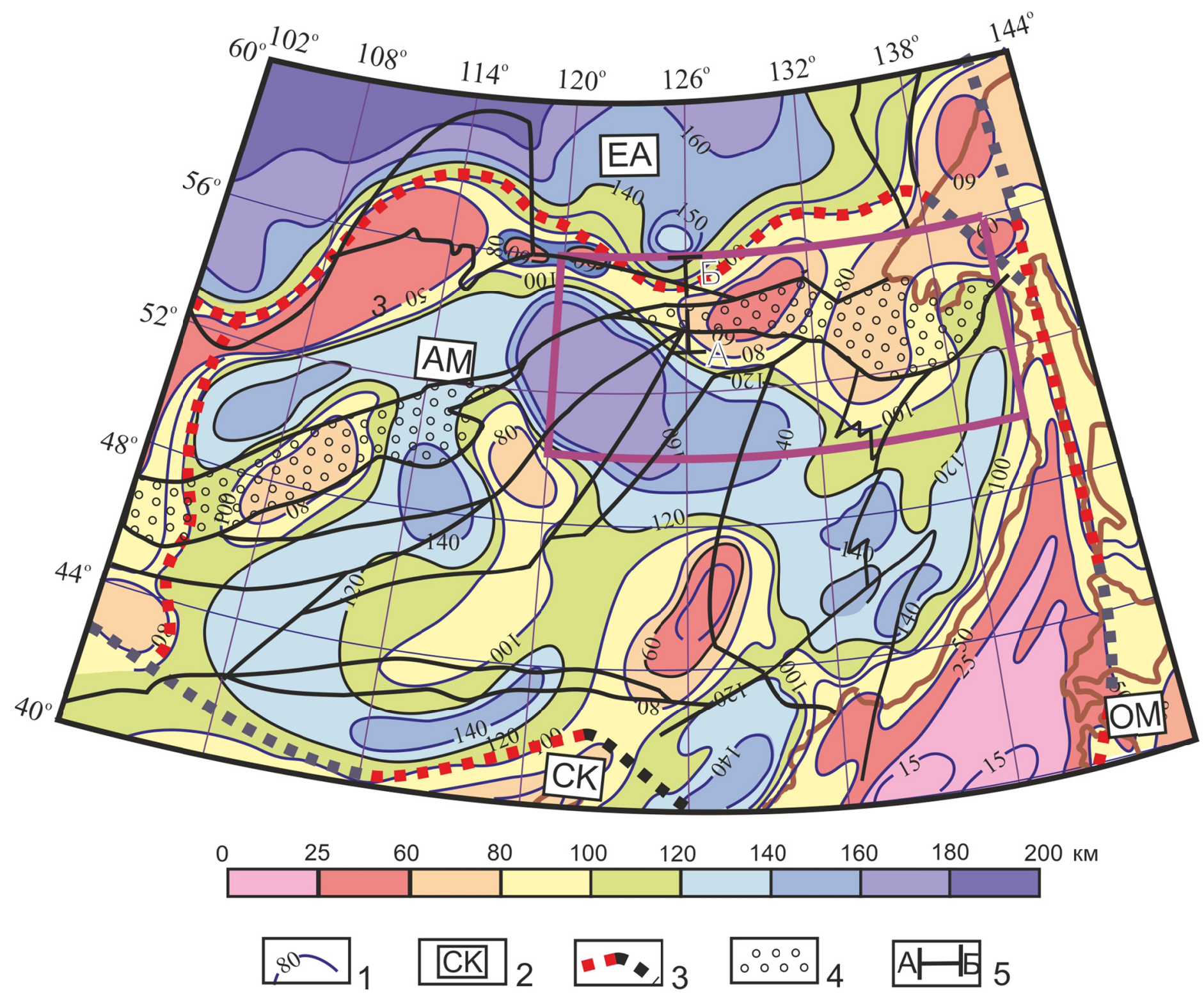

Рис. 3. Положение Монголо-Охотского орогенного пояса в структуре подошвы литосферного слоя.

1 - изопахиты литосферного слоя, км; 2 - литосферные плиты: ЕА - Евразийская, СК - Северо-Китайская, АМ - Амурская, ОМ - Охотоморская; 3 - глубинное ограничение Амурской литосферной плиты (цвет - тип границ: красный - градиентные, черный - трансформные); 4 - Монголо-Охотский орогенный пояс; 5 - месторасположение опорного глубинного профиля; остальные условные обозначения на рис. 1.

Fig. 3. Position of the Mongol-Okhotsk orogenic belt in the structure of the lithospheric layer's base.

1 - isopachytes of the lithospheric layer, km; 2 - lithospheric plates: EA - Eurasian, CK - North-Chinese, AM - Amurskaya, OM - Okhotomorskaya; 3 - deep boundary of the Amurskaya lithospheric plate (colour codes of boundaries: red - gradient, black - transform); 4 - MongolOkhotsk orogenic belt; 5 - location of the reference deep profile; other symbols are given in Fig. 1.

всех последующих поверхностных тектонических элементов (рис. 4).

Внутреннее строение литосферного слоя восточного фрагмента Монголо-Охотского орогена представлено на рис. 5.

Двухмерная геолого-геофизическая модель литосферного слоя в сечении восточного фрагмента Монголо-Охотского орогенного пояса составлена на осно- вании комплексных геолого-геофизических исследований вдоль профиля 3-ДВ [Didenko et al., 2013].

Структурные элементы модели - направление и углы падения разломных систем, наиболее вероятные вещественные характеристики верхней части геологогеофизического разреза, наличие в верхней мантии предполагаемых очагов формирования флюидного вещества в сочетании с палинспастическими реконст- 


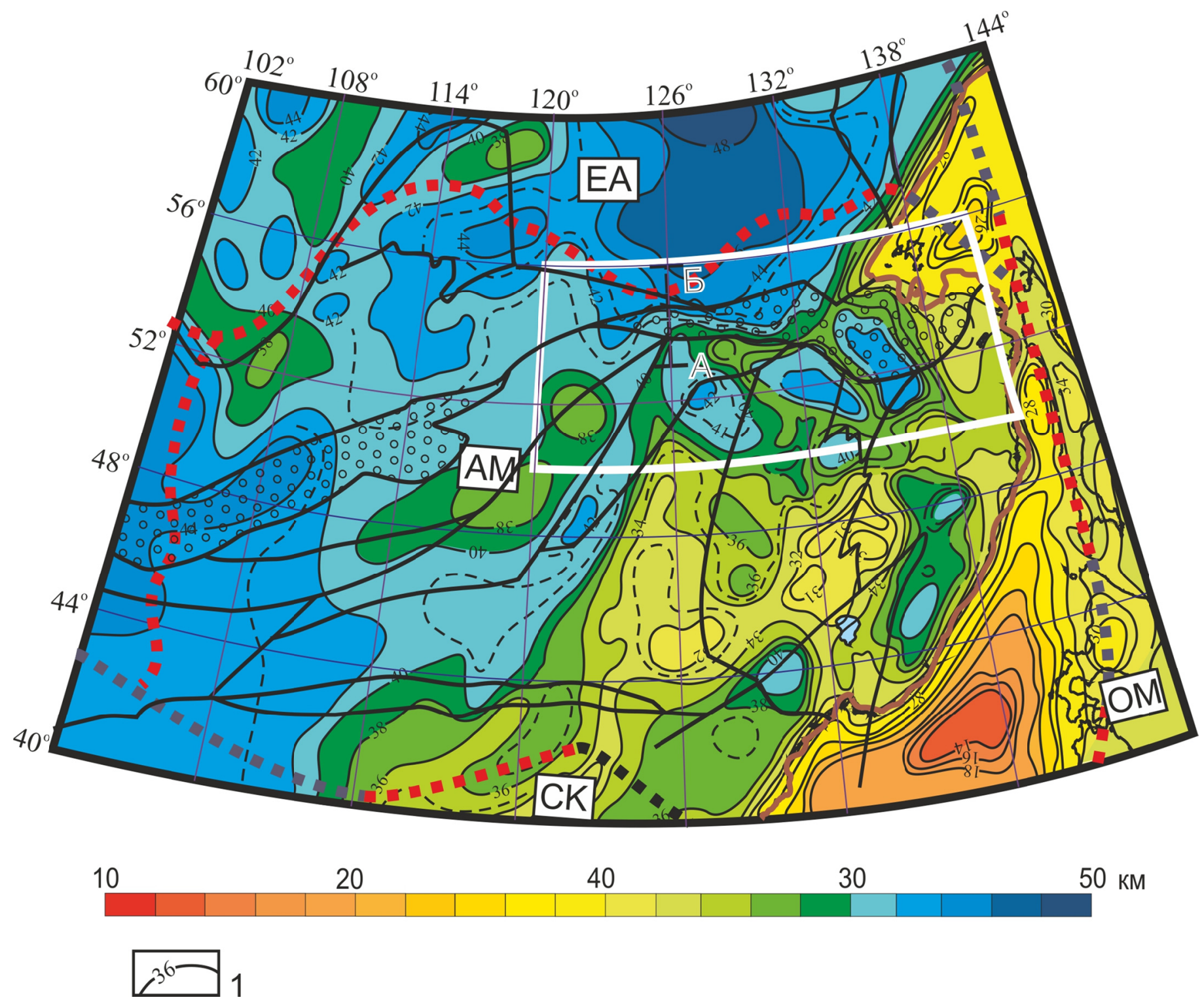

Рис. 4. Положение Монголо-Охотского орогенного пояса в структуре подошвы земной коры.

1 - изопахиты корового слоя, км; остальные условные обозначения на рис. 1, 3.

Fig. 4. Position of the Mongol-Okhotsk orogenic belt in the structure of the crustal base.

1 - isopachytes of the crustal layer, km; other symbols are given in Fig. 1 and Fig. 3.

рукциями [Didenko et al., 2010] - усилили доказательную базу для создания эволюционной модели развития Монголо-Охотского орогенного пояса.

\section{5. ВОЗМОЖНАЯ МОДЕЛЬ (СЦЕНАРИЙ) ФОРМИРОВАНИЯ МОНГОЛО-ОХОТСКОГО ОРОГЕННОГО ПОЯСА}

Привлечение палеомагнитных данных и информации о структурных особенностях современного глубинного строения земной коры и литосферы позволило уточнить особенности эволюции исследуемой об- ласти [Didenko et al., 2010, 2013]. На основании палеомагнитных данных были выполнены глобальные палинспастические реконструкции для изучаемых тектонических структур восточного фрагмента ЦентральноАзиатского подвижного пояса. В итоге представляется следующая последовательность тектонического развития территории исследований.

Океанический бассейн существовал на месте Монголо-Охотского пояса, по крайней мере, с ордовика, что фиксируется по присутствию в Агинском террейне океанических образований этого возраста (440 млн лет) [State Geological Map..., 2010]. Наличие в северном (в современных координатах) обрамлении бас- 





Рис. 5. 2D-модель глубинного строения литосферы восточного фрагмента Монголо-Охотского орогенного пояса (по [Didenko et al., 2013], с дополнениями).

$a$ - графики распределения петрофизических характеристик горных пород: 1 - плотности, 2 - магнитной восприимчивости, 3 - тектонические элементы земной коры: А-М - Аргуно-Мамынский микроконтинент, М-О - Монголо-Охотский и С-С - Селенга-Становой орогенные пояса; 4 - разломы: Южно-Тукурингрский (1), Северо-Тукурингрский (2), Джелтулакский (3); АБ - линия проложения глубинного разреза; $\sigma$ - структурно-геофизический разрез: геофизические границы делимости по магнитометрическим (1), сейсмическим (2), гравиметрическим (3) данным; скоростные слои Vр в км/с со значениями: до 4.0 - (4), до 5.6 - (5), до 6.4 - (6); плотность горных пород в $\mathrm{n} \cdot 10^{3}$ кг/м3 (7); в - комплексы горных пород: 1 - тындинско-бакаранский комплекс $\left(\mathrm{J}_{3}-\mathrm{K}_{1}\right)$ : гранодиориты; 2 - стрелкинская свита (J $\left.\mathrm{J}_{3}-\mathrm{K}_{1}\right)$ : конгломераты, песчаники, алевролиты; 3 - амуджиканский комплекс $\left(\mathrm{J}_{3}\right)$ : граносиениты и гранодиориты; 4 - юрские отложения Верхнеамурского прогиба; 5 - пиканский комплекс $\left(\mathrm{PZ}_{3}\right)$ : габбро, пироксениты, перидотиты, дуниты; 6 - омутнинская свита (S): песчаники, кварциты, сланцы; 7 - тукурингрский комплекс $\left(\mathrm{PR}_{2}\right)$ : граниты и гранодиориты (1), позднестановой комплекс $\left(\mathrm{PR}_{2}\right)$ : субщелочные граниты и гранодиориты (2); 8 - джелтулакская серия $\left(\mathrm{PR}_{2}\right)$ : метапесчаники, сланцы, мраморы, метабазальты; 9 - каменковский комплекс $\left(\mathrm{PR}_{2}\right)$ : граниты, гранитогнейсы; 10 - гонжинский комплекс $\left(\mathrm{PR}_{2}\right):$ граниты гнейсовидные; 11 - гонжинская серия $\left(\mathrm{PR}_{1}\right)$ : гнейсы и кристаллосланцы; 12 - верхний архей $\left(\mathrm{AR}_{2}\right)$ : гнейсы и кристаллосланцы; 13 - нижний архей $\left(\mathrm{AR}_{1}\right)$ : гнейсы и кристаллосланцы; 14 - разрыв-

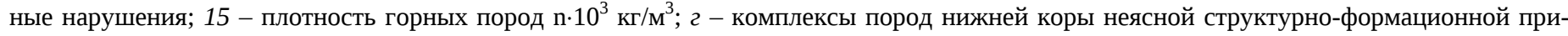
надлежности (1), литосферной мантии (2, 3, 4): I - Аргуно-Мамынского микроконтинента (постпротерозойская), II - Монголо-Охотского орогена (фанерозойская), III - Алдано-Станового щита (постархейская); граница подошвы земной коры (5), литосферной мантии (6); след мантийных флюидных потоков - области высокой электропроводимости (7); (остальные условные обозначения на рис. 5, в).

Fig. 5. 2D model of the deep structure of the lithosphere in the eastern fragment of the Mongol-Okhotsk orogenic belt (according to [Didenko et al., 2013], including additional data).

$a$ - distribution curves of petrophysical characteristics of rocks: 1 - density, 2 - magnetic susceptibility, 3 - tectonic elements of the crust: A-M Arguno-Mamynsky microcontinent, M-O - Mongol-Okhotsk orogenic belt, C-C - Selenga-Stanovoy orogenic belt; 4 - faults: Southern Tukuringrsky (1), Northern Tukuringrsky (2), Dzheltulaksky (3); АБ - line of deep profile; $\sigma$ - structural geophysical cross-section: geophysical boundaries of divisibility according to magnetometric (1), seismic (2), gravimetric (3) data; velocity layers, Vp (km/sec) and values: up to 4.0 (4), up to 5.6 (5), up to 6.4 (6); density of rocks, $\mathrm{n} \cdot 10^{3} \mathrm{~kg} / \mathrm{m} 3$ (7); 8 - rock units: 1 - Tunda-Bakaransky rock unit $\left(\mathrm{J}_{3}-\mathrm{K}_{1}\right)$ : granodiorites; 2 - Strelkinskaya suite $\left(\mathrm{J}_{3}-\mathrm{K}_{1}\right)$ : conglomerates, sandstones, aleurolites; 3 - Amudzhikansky rock unit $\left(\mathrm{J}_{3}\right)$ : granosienites and granodiorites; 4 - Jurassic sediments of the Verkhneamursky trough; 5 - Pikansky rock unit $\left(\mathrm{PZ}_{3}\right)$ : gabbro, pyroxenites, peridotites, dunites; 6 - Omutninskaya suite (S): sanstones, quarzites, shales; 7 - Tukuringrsky rock unit $\left(\mathrm{PR}_{2}\right)$ : granites and granodiorites (1), Late Stanovoy rock unit $\left(\mathrm{PR}_{2}\right)$ : subalkaline granites and granodiorites (2); 8 - Dzheltulakskaya suite $\left(\mathrm{PR}_{2}\right)$ : metasandstones, shales, marbles, metabasalts; 9 - Kamenkovsky rock unit $\left(\mathrm{PR}_{2}\right)$ : granites, granitogneisses; 10 - Gonzhinsky rock unit $\left(\mathrm{PR}_{2}\right)$ : gneissoid granites; 11 - Gonzhinskaya series $\left(\mathrm{PR}_{1}\right)$ : gneisses and crystalline shales; 12 - Upper Archean $\left(\mathrm{AR}_{2}\right)$ : gneisses and crystalline shales; 13 - Lower Archean $\left(\mathrm{AR}_{1}\right)$ : gneisses and crystalline shales; 14 - faults; 15 - density of rocks $\left(\mathrm{n} \cdot 10^{3} \mathrm{~kg} / \mathrm{m}^{3}\right) ; 2$ - rock units of the lower crust which structural formation identity is obscure (1), and rock units of the lithospheric mantle (2, 3, 4): I - Arguno-Mamynsky microcontinent (Post-Proterozoic), II - Mongol-Okhotsk orogen (Phanerozoic), III - Aldan-Stanovoy shield (PostArchean); boundaries of the bases of the crust (5) and lithospheric mantle (6); traces of mantle fluid flows - areas of high electric conductivity (7); other symbols are given in Fig. 5, 8 .

сейна гранодиоритов - гранитных батолитов с возрастом 432 млн лет, относящихся к известково-щелочной серии, позволяет предполагать возможность в это время субдукции под Палеосибирский континент [Kazimirovskiy, 2004].

Следующий импульс раскрытия океана приходится на девон, о чем свидетельствует достаточно полно представленная Пришилкинская офиолитовая ассоциация, которая присутствует в восточной части Ононского фрагмента. Для габброидов этой ассоциации определен возраст 415-388 млн лет [Ruzhentsev, Nekrasov, 2009]. С девонским этапом связывается начало субдукционных процессов в южном обрамлении пояса. Вдоль окраины Монголо-Охотского океана на Амурском (Аргуно-Мамынском) микроконтиненте локализуется Норовлинская окраинно-континентальная дуга. В западной части пояса известны адацагские

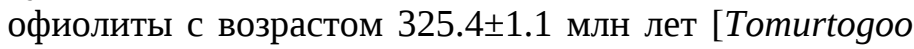
et al., 2005].

В Тукурингра-Джагдинском фрагменте присутствует среднепермский Дугдинский офиолитовый комплекс. Входящие в его состав габброиды имеют возраст 271土2 млн лет [Sorokin et al., 2004]. В позднем палеозое
- раннем мезозое зона субдукции предполагается вдоль северной окраины Амурского (Аргуно-Мамынского) микроконтинента. Она маркируется Восточно-Монгольским вулканическим поясом и магматическими образованиями, продолжающими его к северо-востоку вплоть до северной окраины Аргунского террейна. Вместе с тем, в северном обрамлении западного сектора Монголо-Охотского орогенного пояса располагается Селенгинский вулканоплутонический пояс пенсильваний-раннетриасового возраста. Пояс образован преимущественно продуктами известково-щелочного магматизма в нижней части разреза, которые в конце перми - триасе сменяются бимодальными щелочными вулканитами [Gordienko, 1987; Kozubova et al., 1982; Kovalenko et al., 1983]. Предполагается, что Селенгинский вулканоплутонический пояс связан с трансформным разломом вдоль границы континент-океан и в начале своего развития сопровождался субдукцией под окраину континента [Parfenov et al., 2003].

След этих тектономагматических событий как минимум с раннего мезозоя, по нашим представлениям, зафиксирован в структуре подошвы литосферного слоя (см. рис. 3). 
Проекция на земную поверхность глубинной границы Амурской литосферной плиты смещена на север относительно Ланской и Улигданской разломных систем. Указанные разломы [Tectonics..., 2008] являются северным ограничением комплексов пород, слагающих восточный фрагмент Монголо-Охотского орогена. Этот факт является дополнительным свидетельством достаточно длительного процесса его (восточного фрагмента) погружения под Сибирскую платформу.

Присутствие следов океанической палеолитосферы просматривается в ее сокращенной мощности под образованиями как западного (до 80 км), так и восточного (до 60 км) фрагмента Монголо-Охотского орогена. Меньшие значения глубин до поверхности астеносферного слоя в пределах восточного фрагмента орогена относительно западного свидетельствуют о наличии временного тренда в его развитии, что и отмечается по геологическим данным - более раннее становление западной части и более позднее - восточной. Л.П. Зоненшайном с соавторами [Zonenshain et al., 1990] показано, что образование деформированной структуры Монголо-Охотского орогенного пояса в западной его части началось в позднем карбоне и последовательно продвигалось к востоку, по направлению к Тихому океану, вплоть до середины юры. Оно сопровождалось образованием гигантской Алтайской ороклинали. В ядре ороклинали располагается западное «слепое» окончание Монголо-Охотского орогенного пояса. К ядерной, наиболее сжатой, части ороклинали приурочены пенсильваний-раннепермские батолиты, которые прорывают уже деформированные толщи западной части Монголо-Охотского орогенного пояса и более древние образования его западного, северного и южного обрамления.

В позднем триасе - средней юре продолжается формирование Монголо-Охотского орогенного пояса, сопровождавшееся левосторонним сдвиговым перемещением вдоль Главного Монголо-Охотского разлома.

В начале раннего мела практически полностью закрылся Монголо-Охотский бассейн. Сибирь, продолжавшая столкновение с левосторонне перемещавшейся Сино-Кореей-Монголией, заняла положение, близкое к современному. Над зоной субдукции формируется Удская вулканическая дуга с терригенной преддуговой террасой и аккреционной призмой - Джагдинско-Кербинской зоной Монголо-Охотского пояса.

Этот этап развития литосферы (более позднее закрытие восточного фрагмента палеобассейна) находит свое подтверждение в особенностях структуры подошвы земной коры (см. рис. 4). Для западного фрагмента это практически конформная литосферной структуре и, по-видимому, устоявшаяся во времени синклинорная форма в подошве коры. Для восточного фрагмента в первую очередь это градиентная область, в поверхности подошвы коры осложненная вдоль ее южной границы разнонаправленными по глубине (поднятиеопускание) блоками.
В этот период происходят разнонаправленные сдвиговые перемещения вдоль Главного Монголо-Охотского разлома и Западно-Охотской системы разломов. В частности, Галамский террейн аккреционного клина, который расположен на северо-восточной окраине Монголо-Охотского орогенного пояса (находится в области максимального горизонтального градиента изменения мощности земной коры), занял свое современное положение после правосторонних сдвиговых перемещений вдоль Монголо-Охотского пояса, по-видимому, в самом конце мезозоя. Правые сдвиги отмечены как на его северной границе (Улигданский сдвиг) [Kirillova, Turbin, 1979], так и внутри Галамского террейна [Natal'in, Borukaev, 1991; Natal'in, Popeko, 1991].

В интервале маастрихт - эоцен для литосферы восточной части Азиатского континента заканчиваются аккрекционные процессы, начинается погружение Тихоокеанской плиты под континент, которая движется в северном направлении под острым углом к нему. Трансформная граница континента в районе современного Охотского моря, возможно, сопрягается с конвергентной границей.

В пределах восточного фрагмента Монголо-Охотского орогена к этому времени закончились тектономагматические процессы - формирование интрузивных массивов (Джалиндинский) с соответствующей золоторудной минерализацией (рис. 5) [Shevchenko, Nevstruyev, 2013].

С олигоцена состоявшийся коллаж террейнов приобретает облик современной Амурской тектонической плиты [Parfenov et al., 2003].

\section{6. ЗАКЛЮЧЕНИЕ}

Комплексное использование результатов стратиграфических, седиментологических исследований, структурного анализа дислокаций, изучения хорологической структуры фаунистических сообществ позволило реконструировать основные события в истории формирования Монголо-Охотского орогенного пояса. В результате синтеза разнородных и разномасштабных геофизических моделей получены новые представления и усилены позиции ранее существующих представлений о тектонической структуре литосферы области сочленения южной части Северо-Азиатского кратона с восточным фрагментом Монголо-Охотского орогена, являющегося одним из структурных элементов Центрально-Азиатского подвижного пояса.

На основании сравнительного геологического анализа по составу террейнов, слагающих МонголоОхотский ороген, было сделано предположение о приуроченности Галамского террейна к Охотско-Корякскому орогенному поясу. Последний, в современных географических координатах, находится значительно севернее. С учетом проведенных палеогеодинамических построений вывод о перемещении Галамского 
террейна в южные широты получает дополнительное обоснование.

Геометрия модельных глубинных границ восточного фрагмента орогена - более крутое падение разломных систем, прослеживающееся до уровня подошвы литосферы на юг, и менее крутое - на север $\left(45^{\circ}\right.$ и менее) - является дополнительным доказательством значительного развития надвигов (поддвигов) на границе южной части Северо-Азиатского кратона со структурами восточной части Центрально-Азиатского подвижного пояса в период завершающей стадии закрытия Монголо-Охотского палеоокеана.

Сокращенная мощность литосферного слоя под всей поверхностной структурой Монголо-Охотского орогенного пояса свидетельствует об океанической природе его литосферы (палеолитосферы). Различия в мощности литосферы орогена (в западном фрагменте она более мощная, чем в восточном) соответствуют геологическим данным о длительном и разновременном направленном с запада на восток процессе закрытия Монголо-Охотского палеобассейна. Структурные построения до уровня подошвы земной коры, ее морфологические особенности не противоречат сделанному выше выводу.

Работа выполнена по программе фундаментальных исследований ДВО РАН «Дальний Восток» (проекты 12-I-0-OH3-07, 12-II-CO-08-026) и при поддержке РФФИ (проект 12-05-00088а).

\section{7. ЛИТЕРАТУРА / REFERENCES}

Belyaeva G.V., 1987. Biogeography of the Early Cambrian of the Far East. In: Evolution of geologic processes of the Far East. DVNTs AN SSSR Publishing House, Vladivostok, p. 92-109 (in Russian) [Беляева Г.В. Биогеография раннего кембрия Дальнего Востока // Эволюция геологических процессов Дальнего Востока. Владивосток: Изд-во Дальневосточного научного центра АН СССР, 1987. С. 92-109].

Decisions of the IV Interdepartmental regional stratigraphic meeting on the Precambrian and Phanerozoic of the southern Far East and Eastern Transbaikal region (Khabarovsk, 1990), 1995. Khabarovsk State Mining and Geological Enteprise, Khabarovsk (in Russian) [Решения IV межведомственного регионального стратиграфического совещания по докембрию и фанерозою юга Дальнего Востока и Восточного Забайкалья. Хабаровск: Издание Государственного горно-геологического предприятия, 1995].

Didenko A.N., Efimov A.S., Nelybin P.A., Sal'nikov A.S., Starosel'tsev V.S., Shevchenko B.F., Goroshko M.V., Gyr'yanov V.A., Zamozhnyaya N.G., 2013. Structure and evolution of the Earth's crust in the region of junction of the Central Asian Fold Belt and the Siberian Platform: Skovorodino - Tommot profile. Russian Geology and Geophysics 54 (10), 12361249. http://dx.doi.org/10.1016/j.rgg.2013.09.008.

Didenko A.N., Kaplun V.B. Malyshev Yu.F., Shevchenko B.F., 2010. Lithospheric structure and Mesozoic geodynamics of the eastern Central Asian orogen. Russian Geology and Geophysics 51 (5), 492-506. http://dx.doi.org/10.1016/ j.rgg.2010.04.006.

Dobretsov N.L., Karsakov L.P., Sklyarov Ye.V., 1988. Glaucophane schist belts of South Siberia and the Amur region. Geologiya i Geofizika (Russian Geology and Geophysics) (1), 3-11 (in Russian) [Добрецов Н.Л., Карсаков Л.П., Скляров E.B. Глаукофансланцевые пояса Южной Сибири и Приамурья // Геология и геофизика. 1998. № 1. С. 3-11].

Geology of the USSR. V. XIX. Khabarovsk Territory and Amur region, 1966. Nedra Publishing House, Moscow, 736 p. (in Russian) [Геология СССР, Т. ХІХ, Хабаровский край и Амурская область. М.: Недра, 1966. 736 с.].

Gordienko I.V., 1987. Paleozoic Magmatism and Geodynamics of the Central Asian Fold Belt. Nauka Publishing House, Moscow, 238 p. (in Russian) [Гордиенко И.В. Палеозойский магматизм Центрально-Азиатского складчатого пояса. М.: Наука, 1987. 238 с.].

Gratsianova R.T., Shishkina G.R., 1982. The features of paleobiogeography of continents and seas in the Devonian (from brachiopod study evidence). In: Environment and life in the geologic past. Paleolandscapes and biofacies. Nauka, Moscow, p. 27-45 (in Russian) [Грацианова P.T., Шишкина Г.Р. Особенности палеобиогеографии материков и морей девона (по данным изучения брахиопод) // Среда и жизнь в геологическом прошлом. Палеоландшафты и биофации. М.: Наука, 1982. С. 27-45].

Gusev G.S., Khain V.Ye., 1995. Interrelations between the Baikal-Vitim, Aldan-Stanovoy, and Mongol-Okhotsk terranes (southern part of Middle Siberia). Geotektonika (Geotectonics) (5), 68-82 (in Russian) [Гусев Г.С., Хаин В.Е. О соотношениях Байкало-Витимского, Алдано-Станового и Монголо-Охотского террейнов (юг Средней Сибири) // Геотектоника. 1995. № 5. С. 68-82].

Kazimirovskiy M.E., 2004. Geochemistry of Paleozoic granitoid magmatism in the West Stanovoy zone of Transbaikalia. Geologiya i Geofizika (Russian Geology and Geophysics) 45 (3), 347-362.

Khanchuk A.I., 2000. Paleogeodynamic analysis of formation of ore deposits in the Far East. In: Ore deposits of continental margins. Dalnauka Publishing House, Vladivostok, p. 5-34 (in Russian) [Ханчук А.И. Палеогеодинамический анализ формирования рудных месторождений Дальнего Востока России // Рудные месторождения континентальных окраин. Владивосток: Дальнаука, 2000. С. 5-34].

Khanchuk A.I. (Ed.), 2006. Geodynamics, Magmatism and Metallogeny of the Russian East. Book 1. "Dalnauka” Publishing House, Vladivostok, 572 p. (in Russian) [Геодинамика, магматизм и металлогения востока России / Под ред. А.И. Ханчука. Кн. 1. Владивосток: Изд-во Дальнаука, 2006. 572 с.]. 
Khanchuk A.I., Belyaeva G.V., 1993. Relationship between the terranes of Paleoasian and Paleopacific oceans in the Far East, Russia. In: Dobretsov N.L. and Berzin N.A. (Eds.). Geodynamic evolution of Paleoasian ocean. Report No. 4 of IGCP Project 283. Novosibirsk, p. 84-86.

Khanchuk A.I., Golozubov V.V., Panchenko I.V., Ignatyev A.V., Chudaev O.V., 1992. Ganychalan terrane of the Koryak Upland. Tikhookeanskaya Geologiya (Russian Journal of Pacific Geology) (4), 82-93 (in Russian) [Ханчук А.И., Голозубов В.В., Панченко И.В., Игнатьев А.В., Чудаев О.В. Ганычаланский террейн Корякского нагорья // Тихоокеанская геология. 1992. № 4. С. 82-93].

Kirillova G.L., Turbin M.T., 1979. Formations and Tectonics of the Dzhagdy Link, Mongol-Okhotsk Fold Area. Nauka Publishing House, Moscow, 116 p. (in Russian) [Кириллова Г.Л., Турбин M.T. Формации и тектоника Джагдинского звена Монголо-Охотской складчатой области. М.: Наука, 1997. 116 с.].

Kovalenko V.I., Mossakovskiy A.A., Yarmolyuk V.V., 1983. The problems of reconstruction of geodynamic settings, and petrochemical zoning (as exemplified by the Late Paleozoic volcanic belt of Mongolia). Geotektonika (Geotectonics) (6), 13-29 (in Russian) [Коваленко В.И., Моссаковский А.А., Ярмолюк В.В. Проблемы реконструкции геодинамических условий и петрохимическая зональность (на примере позднепалеозойского вулканического пояса Монголии) // Геотектоника. 1983. № 6. С. 13-23].

Kozakov I.K., Sal'nikova E.B., Kotov E.B., 2005. Age limits and geodynamic setting of forming crystalline complexes in the eastern segment of the Central Asia fold belt. In: Problematic issues of the Central Asia tectonics. GEOS Publishing House, Moscow, p. 56-73 (in Russian) [Козаков И.К., Сальникова Е.Б., Котов Е.Б. 2005. Возрастные рубежи и геодинамическая обстановка формирования кристаллических комплексов восточного сегмента Центрально-Азиатского складчатого пояса // Проблемы тектоники Центральной Азии. М.: ГЕОС, 2005. С. 56-73]

Kozlovskiy Ye.A. (Ed.), 1988. Geology of the BAM Zone. V. 1. Geologic Structure. Nedra Publishing House, Leningrad, 443 p. (in Russian) [Геология зоны БАМ. Т. 1. Геологическая структура / Ред. Е.А. Козловский. Ленинград: Издательство Недра, 1988. 443 с.].

Kozubova L.A., Abramovich I.I., Klushin I.G., 1982. Magmatism and plate tectonics of the Mongol-Transbaikal fold system and its margins. In: Correlation of endogenic processes of the Siberian platform and its margins. Publishing House of SB RAS, Novosibirsk, p. 120-127 (in Russian) [Козубова Л.А., Абрамович И.И., Клушин И.Г. Магматизм и плитная тектоника Монголо-Забайкальской складчатой системы и ее обрамления // Корреляция эндогенных процессов Сибирской платформы и ее обрамления. Новосибирск: Изд-во СО РАН, 1982. С. 120-127].

Krasnyi L.I., Volskii A.S., Yungbiao Peng, Ying Wang, Amantov V.A., Akhmetov R.N., Bazhanov V.A., Bezverkhnii V.L., Bersenev I.I., Biryulkin G.V., Chen Desen, Karsakov L.P., Li Donghan, Liu Jixue, Martynyuk M.V., Nazarenko L.F., Popov O.A., Rybalko V.A., Shatkov G.A., Sidorov V.A., Sorokin A.P., Vaskin A.F., Vasyuk I.B., Volskaya I.P., Wang Kexuan, Xu Yangqiang, Zablotskii E.M., Zhang Hairi, Zhou Qingren, Firsov A.M., Chaban N.N., 1999. Geologic Map of the Amur region and adjacent territories. Explanatory Note to the Geologic Map, scale: 1:2500000. St.-Petersburg, Blagoveshchensk, Harbin, 135 p. (in Russian) [Красный Л.И., Вольский А.С., Юньбяо Пэн, Ин Ван, Амантов В.А., Ахметов Р.Н., Бажанов В.А., Безверхний В.Л., Берсенев И.И., Бирюлькин Г.В., Дэсэнь Чэнь, Карсаков Л.П., Дунхань Ли, Цзисюе Лю, Мартынюк М.В., Назаренко Л.Ф., Попов О.А., Рыбалко В.А., Шатков Г.А., Сидоров Ю.Ф., Сорокин А.П., Васькин А.Ф., Васюк И.Б., Вольская И.П., Кэсуань Ван, Яньцян Сюй, Заблоцкий Е.М., Хайжи Чжан, Цинчжэнь Чжоу, Фирсов А.М., Чабан Н.Н. Геологическая карта Приамурья и сопредельных территорий масштаба 1:2500000. Объяснительная записка. Санкт-Петербург - Благовещенск - Харбин, 1999. 135 с.].

Natal'in B.A., 1991. Mesozoic accretion and collision tectonics of the USSR southern Far East. Tikhookeanskaya Geologiya (Russian Journal of Pacific Geology) (5), 3-23 (in Russian) [Натальин Б.А. Мезозойская аккреционная и коллизионная тектоника юга Дальнего Востока СССР // Тихоокеанская геология. 1991. № 5. С. 3-23].

Natal'in B.A., 1993. History and modes of Mesozoic accretion in southeast Russia. The Island Arc 2 (1), 15-34. http://dx doi.org/10.1111/j.1440-1738.1993.tb00072.x.

Natal'in B.A., Borukaev Ch.B., 1991. Mesozoic sutures in the southern Far East of the USSR. Geotektonika (Geotectonics) (1), 64-74 (in Russian) [Натальин Б.А., Борукаев Ч.Б. Мезозойские сутуры на юге Дальнего Востока СССР // Геотектоника. 1991. № 1. С. 64-74].

Natal'in B.A., Popeko L.I., 1991. The Paleozoic of the Galam segment, Mongol-Okhotsk fold system. Tikhookeanskaya Geologiya (Russian Journal of Pacific Geology) (2), 81-89 (in Russian) [Натальин Б.А., Попеко Л.И. Палеозой Галамского сегмента Монголо-Охотской складчатой системы // Тихоокеанская геология. 1991. № 2. С. 81-89].

Natal'in B.A., Popeko L.I., Chebotov S.A., 1985. Tectonics of the West Dzhagdy zone, Mongol-Okhotsk fold belt. Tikhookeanskaya Geologiya (Russian Journal of Pacific Geology) (2), 49-64 (in Russian) [Натальин Б.А., Попеко Л.И., Чеботов С.А. Тектоника Западно-Джагдинской зоны Монголо-Охотского складчатого пояса // Тихоокеанская геология. 1985. № 2. С. 49-64].

Nokleberg W.J., 2010. Metallogenesis and Tectonics of Northeast Asia. U.S. Geological Survey Professional Paper 1765, 624 p. http://pubs.usgs.gov/pp/1765.

Nokleberg W.J., Parfenov L.M., Monger J.W.H., Norton I.O., Khanchuk A.I., Stone D.B., Scholl D.W., Fujita K., 2000. Phanerozoic Tectonic Evolution of the Circum-North Pacific. U. S. Department of the Interior, U.S. Geological Survey Professional Paper 1626. 122 p.

Parfenov L.M., Berzin N.A., Khanchuk A.I., Badarch G., Belichenko V.G., Bulgatov A.N., Dril S.I., Kirillova G.L., Kuzmin M.I., Nokleberg W., Prokopyev A.V., Timofeev V.F., Tomurtogoo O., Yan X., 2003. Model of formation of orogenic belts 
of Central and NE Asia. Tikhookeanskaya Geologiya (Russian Journal of Pacific Geology) 22 (6), 7-41 (in Russian) [Парфенов Л.М., Берзин Н.А., Ханчук А.И., Бадарч Г., Беличенко В.Г., Булгатов А.Н., Дриль С.И., Кириллова Г.Л., Кузьмин М.И., Ноклеберг У., Прокопьев А.В., Тимофеев В.Ф., Томуртогоо О., Янь С. Модель формирования орогенных поясов Центральной и Северо-Восточной Азии // Тихоокеанская геология. 2003. Т. 22. № 6. С. 7-41].

Parfenov L.M., Popeko L.I., Tomurtogoo O., 1999. Problems of Tectonics of the Mongol-Okhotsk Orogenic Belt. Tikhookeanskaya Geologiya (Russian Journal of Pacific Geology) 18 (5), 24-43 (in Russian) [Парфенов Л.М., Попеко Л.И., Томуртогоо О. Проблемы тектоники Монголо-Охотского орогенного пояса // Тихоокеанская геология. 1999. T. 18. № 5. С. 24-43].

Parfenov L.M., Nokleberg W.J., Khanchuk A.I., 1998. Compilation principles and the main units of the legend of Geodynamics Map of North and Central Asia, Russia's Far East South, Korea and Japan. Tikhookeanskaya Geologiya (Russian Journal of Pacific Geology) 17 (3), 3-13 (in Russian) [Парфенов Л.М., Ноклеберг У. Дж., Ханчук А.И. Принципы составления и главные подразделения легенды геодинамической карты Северной и Центральной Азии, юга российского Дальнего Востока, Кореи и Японии // Тихоокеанская геология. 1998. Т. 17. № 3. С. 3-13].

Parfenov L.M., Bulgatov A.N., Gordienko I.V., 1996. Terranes and the formation of orogenic belts of the Transbaikal region. Tikhookeanskaya Geologiya (Russian Journal of Pacific Geology) 15 (4), 3-15 (in Russian) [Парфенов Л.М., Булгатов А.Н., Гордиенко И.В. Террейны и формирование орогенных поясов Забайкалья // Тихоокеанская геология. 1996. T. 15. № 4. C. 3-15].

Parfenov L.M., Berdnikov N.V., Voinova I.P., Vrublevskyi A.A., Karsakov L.P., Kirillova G.L., Legler V.A., Natal'in B.A., Popeko V.A., Popeko L.I., Savel'ev A.A., Semenov D.F., Utkin V.P., Ufimtsev G.F., Yushmanov V.V., 1979. Tectonic zonation and Structural and Material Evolution of Northtast Asia. Nauka Publishing House, Moscow, 240 p. (in Russian) [Парфенов Л.М., Бердников Н.В., Войнова И.П., Врублевский А.А., Карсаков Л.П., Кириллова Г.Л., Леглер В.А., Натальин Б.А., Попеко В.А., Попеко Л.И., Савельев А.А., Семенов Д.Ф., Уткин В.П., Уфимцев Г.Ф., Юшманов В.В. Тектоническое районирование и структурно-вещественная эволюция Северо-Востока Азии. М.: Наука, 1979. 240 c.].

Popeko L.I., Natal'in B.A., Belyaeva G.V., Kotlyar G.V., Shishkina G.R., 1993. Paleobiogeographic zoning and geodynamics of the Russian southern Far East. Tikhookeanskaya Geologiya (Russian Journal of Pacific Geology) (5), 19-30 (in Russian) [Попеко Л.И., Натальин Б.А., Беляева Г.В., Котляр Г.В., Шишкина Г.Р. Палеобиогеографическая зональность и геодинамика юга Дальнего Востока России // Тихоокеанская геология. 1993. № 5. С. 19-30].

Roganov G.V., 1976. Tectonics of the Eastern Part of Mongol-Okhotsk Fold Geosyncline Area. Author's abstract of Candidate's (Phd) dissertation. Khabarovsk, 23 p. (in Russian) [Роганов Г.В. Тектоника восточной части МонголоОхотской складчатой геосинклинальной области: Автореф. дис. ... канд. геол.-мин. наук. Хабаровск, 1976. 23 с.].

Ruzhentsev S.V., Nekrasov G.E., 2009. Tectonics of the Aga Zone, Mongolia-Okhotsk belt. Geotectonics 43 (1), 34-50. http://dx.doi.org/10.1134/S0016852109010038.

Shevchenko B.F., Nevstruyev V.G., 2013. Deep structure and geochemical zoning of the Solovyovsk ore district (Upper Priamurie). In: Processes of mineralization and applied geochemistry. IMGRE Publishing House, Moscow, p. 321-331 (in Russian) [Шевченко Б.Ф., Невструев В.Г. Глубинное строение и минералого-геохимическая зональность Соловьевского рудного района (Верхнее Приамурье) // Процессы рудообразования и прикладная геохимия. Москва: Изд-во ИМГРЭ, 2013. С. 321-331].

Sklyarov E.V., 2006. Exgumation of metamorphic complexes: basic mechanisms. Geologiya i Geofizika (Russian Geology and Geophysics) 47 (1), 71-75.

Sklyarov E.V., Fedorovskiy V.S., 2006. Magma mingling: tectonic and geodynamic implications. Geotectonics 40 (2), 120-134. http://dx.doi.org/10.1134/S001685210602004X.

Sklyarov E.V., Mazukabzov A.M., Melnikov A.I., 1997. The Cordilleran-type metamorphic core complexes. Publishing House of SB RAS, Novosibirsk, 182 p. (in Russian) [Скляров Е.В., Мазукабзов А.М., Мельников А.И. Комплексы метаморфических ядер кодильерского типа. Новосибирск: Издательство СО РАН, 1997. 182 с.].

Sorokin A.A., 2001. Paleozoic accretionary complexes of the Mongol-Okhotsk fold belt eastern segment. Tikhookeanskaya Geologiya (Russian Journal of Pacific Geology) 20 (6), 31-36 (in Russian) [Сорокин А.А. Палеозойские аккреционные комплексы восточного сегмента Монголо-Охотского складчатого пояса // Тихоокеанская геология. 2001. T. 20. № 6. C. 31-36].

Sorokin A.A., Kotov A.B., Kudryashov N.M., Salnikova Ye.B., 2004. Geochronology of granitoid and gabbro-tonalite complexes of the eastern segment of Mongol-Okhotsk fold belt and its framing as boundary conditions for geodynamic reconstructions. In: Geodynamic evolution of the lithosphere of the Central Asian mobile belt (from ocean to continent). Materials of the meeting, Vol. 2. Irkutsk, p. 106-110 (in Russian) [Сорокин А.А., Котов А.В., Кудряшов Н.М., Сальникова Е.Б. Геохронология гранитоидных и габбро-тоналитовых комплексов восточного сегмента МонголоОхотского складчатого пояса и его обрамления как граничные условия для геодинамических реконструкций // Геодинамическая эволюция литосферы Центрально-Азиатского подвижного пояса (от океана к континенту). Материалы совещания. Т. 2. Иркутск, 2004. С. 106-110].

State Geological Map of the Russian Federation. Scale 1:1000000. Aldan-Transbaikalian series. Sheet M-50 (Borza). Explanatory note, 2010. Publishing House VSEGEI. St. Petersburg [Государственная геологическая карта Российской Федерации масштаба 1:1 000 000. Издание третье. Серия Алдано-Забайкальская. Лист М-50 (Борзя). Объяснительная записка. СПб.: Картфабрика ВСЕГЕИ, 2010]. 
Tectonics, deep structure, metallogeny of the Central Asian - Pacific Belts Junction Area (Explanatory Notes to the Tectonic Map scale of 1:1500000). 2008. Eds: Karsakov L.P., Zhao Chynjing et al. Geological Publishing House, Beijing, China, 213 p.

Tomurtogoo O., Windley B.F., Kröner A., Badarch G., Liu D.Y., 2005. Zircon age and occurrence of the Adaatsag ophiolite and Muron shear zone, Central Mongolia: constraints on the evolution of the Mongol-Okhotsk ocean, suture and orogen. Journal of the Geological Society of London 162 (1), 125-134. http://dx.doi.org/10.1144/0016-764903-146.

Zonenshain L.P., Kuzmin M.I., Natapov L.M., 1990. Tectonics of Lithospheric Plates of the USSR Territory. Publishing House Nedra, Moscow. Book 1, 326 p. Book 2, 334 p. (in Russian) [Зоненшайн Л.П., Кузьмин М.И., Натапов Л.м. Тектоника литосферных плит территории СССР. М.: Недра, 1990. Кн. 1. 326 с. Кн. 2. 334 с.].

Zorin Yu.A., Belichenko V.G., Turutanov E.Kh., Kozhevnikov V.M., Sklyarov E.V., Tomurtogoo O., Khosbayar P., Arvisbaatar N., Byambaa Ch., 1998. Terranes in East Mongolia and Central Transbaikalia and evolution of the OkhotskMongolian fold belt. Geologiya i Geofizika (Russian Geology and Geophysics) 39 (1), 11-25.

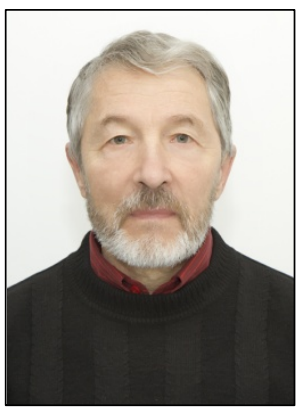

Шевченко Борис Фёдорович, канд. геол.-мин. наук

Институт тектоники и геофизики им. Ю.А. Косыгина ДВО РАН

680000, Хабаровск, ул. Ким Ю Чена, 65, Россия

\e-mail: shevchenko@itig.as.khb.ru

Shevchenko, Boris F., Candidate of Geology and Mineralogy

Yu.A. Kosygin Institute of tectonics and geophysics

65 Kim Yu Chen, Khabarovsk 680000, Russia

e-mail: shevchenko@itig.as.khb.ru

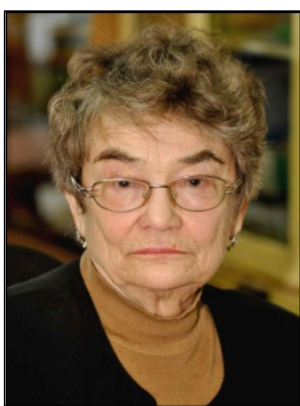

Попеко Людмила Ивановна, канд. геол.-мин. наук Институт тектоники и геофизики им. Ю.А. Косыгина ДВО РАН 680000, Хабаровск, ул. Ким Ю Чена, 65, Россия e-mail: popeko@itig.as.khb.ru

Popeko, Lyudmila I., Candidate of Geology and Mineralogy

Yu.A. Kosygin Institute of tectonics and geophysics

65 Kim Yu Chen, Khabarovsk 680000, Russia

e-mail: popeko@itig.as.khb.ru

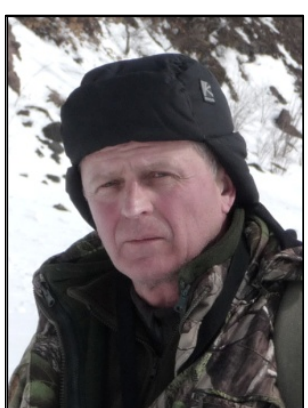

Диденко Алексей Николаевич, докт. геол.-мин. наук

Институт тектоники и геофизики им. Ю.А. Косыгина ДВО РАН 680000, Хабаровск, ул. Ким Ю Чена, 65, Россия

e-mail: itig@itig.as.khb.ru

Didenko, Aleksei N., Doctor of Geology and Mineralogy

Yu.A. Kosygin Institute of tectonics and geophysics

65 Kim Yu Chen, Khabarovsk 680000, Russia

e-mail: itig@itig.as.khb.ru 